\title{
Depoliticisation and the Changing Trajectories of Grassroots Women's Leadership in Peru: From Empowerment to Service Delivery?
}

\author{
KATY JENKINS*
}

Abstract. This paper examines how practices of leadership have been negotiated and have changed over time in the context of a grassroots health promotion project in Lima, Peru. Tracing these trajectories in the context of the evolution of women's organising in Peru informs a broader analysis of the changing role of grassroots women in development projects, feeding into debates around the professionalisation and depoliticisation of grassroots activism and providing new empirical material on gendered experiences of grassroots leadership. The paper recognises the increasing dominance of neoliberal management mechanisms but argues that the depoliticisation of grassroots women leaders is not simply a straightforward trickledown of neoliberal development practices but is produced through the interplay of local socio-political processes and personal biographies of activism with more macro-level development trends and discourses.

Keywords: women's leadership, professionalisation, Peru, empowerment, community organisations, grassroots, depoliticisation

\section{Introduction}

By the mid-200os, when this research was conducted, 'empowerment of women' and 'women's leadership' had become two of many buzzwords absorbed into the vocabulary of the development industry and deployed by neoliberal development agencies in their work throughout the global South. ${ }^{\mathrm{I}}$

Katy Jenkins is a senior lecturer in the Department of Social Sciences at Northumbria University. Email: katy.jenkins@northumbria.ac.uk.

* The ideas expressed in this article are my own and do not necessarily represent the perspective of all the organisations and individuals that participated in this research, to whom thanks are due for their generous participation. Many thanks to Matt Baillie Smith, Nina Laurie and Mary Mellor for their helpful comments on previous versions of this paper, as well as to three anonymous referees and the editors of the JLAS whose comments were extremely valuable in strengthening this paper. This research was funded by ESRC Studentship no. PTA-0302002-01504.

${ }^{\text {I }}$ In particular the World Bank, but also the Inter-American Development Bank and USAID, among others. Mick Moore, 'Empowerment at Last?', Journal of International Development, 
The term 'neoliberal development' is commonly used to denote the collection of practices, ideologies and policies aimed at promoting the rolling back of the state, including privatisation, deregulation, economic liberalisation, removal of tariffs and subsidies, now recognisable in interventions throughout much of the global North and South. ${ }^{2}$ The overarching characteristics of neoliberal development strategies in the South, and more specifically in Latin America, are now very familiar. ${ }^{3}$ However, the processes and practices of neoliberalism are historically contingent and are put into practice in distinct ways in particular local contexts. ${ }^{4}$ Drawing on extensive empirical material, this paper therefore analyses the changing experiences of leadership amongst grassroots women in the specific context of Peru, arguing that the apparent depoliticisation of grassroots women's leadership here is not the result of a straightforward trickledown of neoliberal development practices, but rather must be understood as being produced through the interaction of particular local sociopolitical processes with more macro-level neoliberal development trends. In particular, I outline the ways in which processes of depoliticisation are evidenced in a lack of knowledge transfer and rotating leadership amongst grassroots women; a lack of support aimed at helping grassroots women progress and develop their leadership skills; and a widespread reluctance on the part of grassroots women to take on leadership roles. Implicit throughout this discussion is a consideration of how neoliberal practices may be adopted, resisted, reworked, subverted and/or ameliorated through collective organising. ${ }^{5}$

A long-established grassroots women's organisation in Lima, Peru, provides the empirical context for these discussions. This project, to which I have given the pseudonym 'Integra', is a health promotion project based in a Lima barriada (Barrio Alegre). ${ }^{6}$ It has been run for the last 15 years by a group

I3: 3 (2001), pp. 321-9; Caroline Sweetman, 'Editorial', in Caroline Sweetman (ed.), Women and Leadership (Oxford: Oxfam GB, 2000), pp. 2-7; Andrea Cornwall, 'Buzzwords and Fuzzwords: Deconstructing Development Discourse', Development in Practice, 17: 4-5 (2007), pp. $47 \mathrm{I}-84$.

${ }^{2}$ Nina Laurie and Liz Bondi (eds.), Working the Spaces of Neoliberalism: Activism, Professionalisation and Incorporation (London: Blackwell, 2005).

3 Thomas Perrault and Patricia Martin, 'Geographies of Neoliberalism in Latin America: An Introduction', Environment and Planning A, 37: 2 (2005), pp. 19I-20I; Paul Cammack, 'Neoliberalism, the World Bank, and the New Politics of Development', in Uma Kothari and Martin Minogue (eds.), Development Theory and Practice: Critical Perspectives (Basingstoke: Palgrave, 2002), pp. 1 57-78.

4 Jamie Peck and Adam Tickell, 'Neoliberalizing Space', Antipode, 34: 3 (2002), pp. 380-404; Wendy Larner, 'Neoliberalism: Policy, Ideology, Governmentality', Studies in Political Economy, 63 (2000), pp. 5-25; Maxine Molyneux, "The "Neoliberal Turn" and New Social Policy in Latin America: How Neoliberal, How New?', Development and Change, 39: 5 (2008), pp. 775-97. 5 Laurie and Bondi (eds.), Working the Spaces of Neoliberalism.

6 The term 'barriada' refers to the informal settlements or shanty towns that developed on the outskirts of Lima from the 1950 s onwards. 
of $\mathrm{I} 2$ volunteer women health promoters, and is overseen and funded by a renowned Peruvian feminist NGO, 'Esperanza'. 7 The health promoters are all local community women, aged between 31 and 56 at the time of the research, who were all either born in Lima or had migrated there at a young age. Life history interviews conducted with these women provide the basis for an exploration of how notions of leadership have been negotiated over time in the context of the health promotion project. ${ }^{8}$ This analysis informs a broader understanding of the changing role and position of grassroots women leaders in development projects, and feeds into debates on the professionalisation of activism, emphasising that macro-level development paradigms cannot be detached from the personal biographies and local contexts of development activists. ${ }^{9}$

The paper takes an interdisciplinary approach, bringing together literature on critiques of neoliberal development and the professionalisation of activism, principally from development studies and human geography, with debates on the trajectories of women's organising in a specifically Peruvian context. The paper begins with an overview of the changing nature of notions of empowerment and leadership at the macro policy level, moving on to consider the ways in which such discourses have influenced, and are evident in, the historical trajectories of women's activism in Peru. I then explore the unique factors surrounding the subsequent depoliticisation of these spaces before moving on to engage more substantively with the case study material, analysing changing leadership roles at the Integra health promotion project and using personal narratives to argue that the depoliticisation of grassroots leadership should be understood in relation both to neoliberal development trends and to the broader historical Peruvian context.

\section{Framing Women's Leadership: From Empowerment to Efficiency}

Since the I980s, notions of women's empowerment and leadership have been key themes in feminist (particularly third world feminist) development practice, emphasising women as active agents of social change and promoting

7 Contextual detail is left deliberately brief in order to protect the organisations' anonymity.

${ }^{8}$ For a full discussion of the methodology of this research, see Katy Jenkins, 'Feminist Methodologies: Unsettling Multiple Boundaries in Development', in Matt Smith (ed.), Negotiating Boundaries and Borders: Qualitative Methodology and Development Research (Oxford: Elsevier, 2007), pp. 83-103. All names of organisations and individuals in this paper are pseudonyms to protect the anonymity of participants. Data are drawn from life history interviews and participant observation conducted by the author, and quotes have been translated from Spanish by the author.

9 See also Matt Baillie Smith and Katy Jenkins, 'The Personal is Problematic: Activist Biographies and NGO Narratives in South India', paper presented at the Annual Conference of the Association of American Geographers, Washington, DC, 2010. 


\section{Katy Jenkins}

women's empowerment through community organising and transformative action. ${ }^{10}$ Wieringa recognises the fundamentally political nature of 'empowerment' in this context:

The process of empowerment of women is related to all three dimensions: exposing the oppressive power of the existing gender relations, critically challenging them, and creatively trying to shape different social relations. The empowerment approach recognizes the political nature of development processes and stimulates women to become actively engaged as political actors. Political mobilization and consciousnessraising are important elements, and women's organizations are seen as vital actors in development processes. ${ }^{\mathrm{II}}$

Promoting women's leadership was integral to the empowerment approach, and was understood as encouraging women to develop the necessary skills to be leaders in their communities, able to guide, inspire action and mobilise others, with the implicit assumption that good leaders actively promote progress and change. ${ }^{12}$ The empowerment approach has particularly been associated with participatory approaches to health and health education, and is therefore especially relevant to considering the leadership experiences of women health promoters.

However, despite the 'feel-good' nature of the notion of empowerment, ${ }^{13}$ it is a concept for which there is no clearly agreed definition. How does someone become empowered? How do you know if someone is empowered? This leaves the concept open to being appropriated in the service of a wide range of agendas in which the idea of empowerment becomes detached from fundamental issues of power relations. ${ }^{14}$ Reflecting a broader pattern of subsumation of alternative development concepts, potentially transformatory concepts such as leadership, empowerment and participation have been appropriated by multilateral organisations and the mainstream development paradigm as the gender and development agenda has become institutionalised, rendering originally radical and challenging concepts more conformist and mainstream. ${ }^{\text {I5 }}$ Women's empowerment has come to be conflated with notions of efficiency

10 Sweetman, 'Editorial'; Georgina Waylen, Gender in Third World Politics (Boulder, CO: Lynne Rienner, 1996).

I Saskia Wieringa, 'Women's Interests and Empowerment: Gender Planning Reconsidered', Development and Change, 25: 4 (1994), pp. 829-48.

${ }^{12}$ Lesley Abdela, 'From Palm Tree to Parliament: Training Women for Political Leadership and Public life', in Sweetman (ed.), Women and Leadership, pp. 16-23.

${ }^{13}$ Moore, 'Empowerment at Last?'.

${ }^{14}$ Jo Rowlands, Questioning Empowerment: Working with Women in Honduras (Oxford: Oxfam, I 997); Srilatha Batliwala, 'Taking the Power out of Empowerment - An Experiential Account', Development in Practice, 17: 4 (2007), pp. 557-65.

is Frances Cleaver, 'Paradoxes of Participation: Questioning Participatory Approaches to Development', Journal of International Development, I I: 4 ( I 999), pp. 597-6 I 2; Ines Smyth, 'Talking of Gender: Words and Meanings in Development Organisations', Development in Practice, 17: 4 (2007), pp. 582-8. 
and entrepreneurship, stressing 'power to' and 'power with', rather than more feminist and politicised conceptions of empowerment focusing on 'power from within'. ${ }^{16}$ The language of 'empowerment' is increasingly being employed in mainstream development discourses but de-coupled from its original emphasis on challenging social inequalities and encouraging wider structural change. As Batliwala notes, 'the sharp political perspective from which it arose [has become] diffused and diluted'. ${ }^{17}$

As Rowlands also observes, empowerment involves 'more than participation in decision-making; it must also include the processes that lead people to perceive themselves as able and entitled to make decisions'. ${ }^{18}$ However, empowerment within a neoliberal model of development re-casts poor people as 'empowered active citizens capable of formulating their own needs and engaging in the setting of priorities and the implementation of projects', ${ }^{19}$ reducing empowerment to the shifting of responsibilities away from the state rather than promoting a collective process of active self-empowerment.

Within this context, Rao and Kelleher highlight a transition away from strategies promoting a leadership style focused on participation, social change and devolution of power that were espoused by feminist activists and popular organisations throughout the 1980 os and early i 990 . Women's leadership has instead been reconstructed as an element of 'best practice' within the neoliberal paradigm, framed by the requirements of addressing new managerial exigencies such as accountability, efficiency, sound financial management and quantifiable policy results. ${ }^{20}$ Sweetman notes that, in extolling the virtues of women's leadership in achieving development goals, leadership training has become 'an apolitical strategy favoured by development agencies who have adopted the language of power and politics, while doing little to challenge unequal relationships between women and men, the South and the North, and political elites and grassroots communities'. ${ }^{21}$ Thus, while the importance of fomenting grassroots and women leaders is now being widely promoted, the style of leadership that is actually encouraged is much less empowering in its

${ }^{16}$ Rowlands, Questioning Empowerment; Kwok-Fu Wong, 'Empowerment as a Panacea for Poverty - Old Wine in New Bottles? Reflections on the World Bank's Conception of Power', Progress in Development Studies, 3: 4 (2003), pp. 307-22.

${ }^{17}$ Batliwala, 'Taking the Power out of Empowerment', p. 559; Sumi Madhok, 'A Limited Women's Empowerment: Politics, the State, and Development in Northwest India', Women's Studies Quarterly, 31: 3-4 (2003), pp. I 54-73; Cheryl McEwan, 'New Spaces of Citizenship? Rethinking Gendered Participation and Empowerment in South Africa', Political Geography, 24: 8 (2005), pp. 969-91.

${ }_{18}$ Rowlands, Questioning Empowerment, p. 14, emphasis in original.

19 Molyneux, "The "Neoliberal Turn", p. 783.

${ }^{20}$ Aruna Rao and David Kelleher, 'Leadership for Social Transformation: Some Ideas and Questions on Institutions and Feminist Leadership', Gender and Development, 8: 3 (2000), pp. 74-9.

${ }^{21}$ Sweetman, 'Editorial', p. 4. 


\section{Katy Jenkins}

nature. This is reflected in Sweetman's conception of the recent focus on leadership training as an apolitical strategy, often creating a situation of 'training women to train women to train women to train women' rather than initiating a transformatory process whereby women leaders are capacitated to actively mobilise for and implement change. ${ }^{22}$ Dolhinow highlights a similar scenario in the settlements along the US-Mexico border, asserting that, despite the physical improvements that are made through women's collective endeavours there, the activism of these women does not produce politicised leaders with an 'awareness of their marginalisation'. ${ }^{23}$ Such observations resonate with wider concerns about the depoliticisation of feminism as it has been mainstreamed into development agendas, ${ }^{24}$ and can be directly contrasted with earlier aspirations that women's collective organising would provide a mechanism for enabling widespread social and political change. ${ }^{25}$

These shifting development discourses illustrate the extent to which notions of women's empowerment and leadership are becoming increasingly depoliticised. By 'depoliticisation', I refer to the process by which both development concepts and practices become delinked from an engagement with political agendas for social change, and become embedded in broader processes of professionalisation and bureaucratisation of development. ${ }^{26}$ While processes of depoliticisation have been noted in relation to a wide range of development concepts, ${ }^{27}$ this has been particularly prominent in the sphere of gender and development. In this paper I refer specifically to depoliticisation in relation to feminist agendas for gender equity. ${ }^{28}$ These changes provide the backdrop for considering women's leadership in the context of Peru, where it is apparent that a parallel process of broader social depoliticisation has taken place. The rest of this paper analyses how this depoliticisation of grassroots women's activism has shaped evolving leadership practices, emphasising that these changes can only be understood within the local social and political context.

\section{Developing Grassroots Leaders in Lima: Leadership for Change?}

Early experiences of grassroots women's community organising in Peru in the I960s, I970s and I980s have become emblematic if slightly well-worn examples, for scholars of both gender and development and social movement

${ }^{22}$ Abdela, 'From Palm Tree to Parliament'.

${ }^{23}$ Rebecca Dolhinow, 'Caught in the Middle: The State, NGOs, and the Limits to Grassroots Organizing along the US-Mexico border', Antipode, 37: 3 (2005), p. 562.

${ }^{24}$ Smyth, 'Talking of Gender'.

25 Wieringa, 'Women's Interests and Empowerment'.

${ }^{26}$ Shelley Feldman, 'Paradoxes of Institutionalisation: The Depoliticisation of Bangladeshi NGOs', Development in Practice, I 3: I (2003), pp. 5-26.

27 Cornwall, 'Buzzwords and Fuzzwords'.

${ }^{28}$ Batliwala, 'Taking the Power out of Empowerment'; Smyth, 'Talking of Gender'. 
studies, of urban Latin American grassroots women's capacity for organising and self-reliance. ${ }^{29}$ These experiences are central to the trajectory of contemporary Peruvian women's organisations, and therefore merit re-examination specifically in relation to the development and experiences of grassroots women leaders, which have received little attention either in the context of Peru or elsewhere.

Women's organising has characterised barriada communities since their earliest days, as the massive growth of low-income urban settlements brought together large concentrations of workers for the first time. ${ }^{\circ}$ It is from the emergence of clubes de madres (Mothers' Clubs) in these communities in the late I960s that a definitive strand of women's grassroots leadership can be traced. ${ }^{31}$ The clubes de madres were primarily initiated by political parties as a means of securing the votes and allegiance of neighbourhood women. Their organisation tended to be hierarchical and autocratic, with dirigentas (women leaders) relishing their relative power and influence over women members, granting favours and overseeing the distribution of goods to those they considered allies. ${ }^{32}$ The dirigentas were usually women from the community who were in an economically more secure situation and did not need to work, allowing them to devote their time to organising the club and securing patronage from wealthy individuals and organisations. There was a precarious sense of solidarity in these early experiences, with individualism and collectivism existing side-by-side. Both the dirigentas and their members endeavoured to extract as much personal benefit as possible, in the form of donated goods, food and favours, in the absence of more universal mechanisms of state provisioning. ${ }^{33}$ As Blondet notes, 'Precariousness and insecurity reinforce individualism and generate problems and conflicts. Envy grows in the midst of poverty and solidarities are maintained to the extent that they are necessary for survival.'34

29 See, for example, Amy Lind, 'Feminist Post-Development Thought: "Women in Development" and the Gendered Paradoxes of Survival in Bolivia', Women's Studies Quarterly, 31: 3-4 (2003), pp. 227-46.

30 Kenneth M. Roberts, Deepening Democracy? The Modern Left and Social Movements in Chile and Peru (Stanford, CA: Stanford University Press, 1998).

${ }^{31}$ Mothers' clubs gave women the opportunity to come together to share their experiences, creating a sense of common identity as the settlement was established. They tended to support women's traditional domestic roles, with activities including sewing classes and prizes for the tidiest house. Jelke Boesten, 'Poor Women in Peru: Reproducers of Poverty and Poverty Relievers', Women's Studies Quarterly, 3 I: 3-4 (2003), pp. I 1 3-28; Cecilia Blondet, 'Establishing an Identity: Settlers in a Poor Lima Neighbourhood', in Elizabeth Jelin (ed.), Women and Social Change in Latin America (London: Zed Books, 1990).

32 Cecilia Blondet, 'Muchas vidas construyendo una identidad: las mujeres pobladoras de un barrio limeño', in Elizabeth Jelin (ed.), Ciudadania e identidad: las mujeres en los movimientos sociales latino-americanos (Geneva: UNRISD, 1987), pp. 19-73.

33 Ibid.

${ }^{34}$ Ibid., p. 49, my translation. 
Despite the clientelistic and top-down nature of the clubes de madres, they played a crucial role in establishing and sustaining barriada communities, and for the first time provided women with a collective space in which to relate to each other outside the confines of their own homes (yet still broadly within the domestic sphere). The emergence of these women from their homes was groundbreaking, challenging a status quo that constructed public space as the preserve of men and laying important groundwork for more transformative women's organising in the future. Towards the end of the I 970 , the comedores populares developed out of the structures of the clubes de madres. ${ }^{35}$ The comedores were variously instigated and supported by the clubes de madres, the government, the Catholic Church (CEAS and Cáritas), the Evangelical Church (SEPAS), the Adventist Church (OFASA) and the international lay organisation CARE. ${ }^{36}$ Barrig notes a lack of coordination by the government of these various programmes, however, resulting in duplication of provision and 'segmented organizations with different modes of operation', with the state reproducing practices of asistencialismo (welfarism) through selective support for social organisations on the basis of political allegiances. ${ }^{37}$ Blondet and Montero suggest that in later years this lack of coordination also hampered the development of an articulated political agenda among popular women's organisations. ${ }^{38}$ Nevertheless, the comedores burgeoned throughout the various economic crises of the I980s and I990s. By 1996, 'the transfer of resources between poor women and other poor people [had] virtually replaced the withering social function of the state', with the participation of an estimated 250,000 women across Lima. 39 Less autocratic than the clubes de madres, the comedores were bolstered by the involvement of a younger generation of women who brought with them more radical ideas developed through their involvement in popular education centres and parish organisations, and who challenged the autocratic tendencies of the neighbourhood organisations. ${ }^{4}$

The women leaders of the comedores emerged as a driving force in their communities, learning skills such as basic accounting, organising meetings, and

35 The comedores populares are community kitchens organised by groups of women who purchase and prepare food communally in response to ongoing economic upheaval; food is often donated or heavily subsidised.

${ }^{36}$ Cecilia Blondet and Carmen Montero, Hoy: menú popular - comedores en Lima (Lima: IEP and UNICEF, 1995).

37 Maruja Barrig, 'Women, Collective Kitchens and the Crisis of the State in Peru', in John Friedmann, Rebecca Abers and Lilian Autler (eds.), Emergences: Women's Struggles for Livelihood in Latin America (Los Angeles: UCLA Latin American Center Publications, I996), p. 6I.

${ }^{8}$ Blondet and Montero, Hoy: menú popular.

39 Barrig, 'Women, Collective Kitchens and the Crisis of the State', p. 65.

${ }^{40}$ Blondet, 'Muchas vidas construyendo una identidad'. See also Cecilia Blondet, Las mujeres y el poder: una historia de Villa el Salvador (Lima: Instituto de Estudios Peruanos, 1991). 
negotiating with government and donor organisations. ${ }^{4 \mathrm{I}}$ Barrig asserts that the 'massive presence' of the comedores populares 'has converted the leaders of the comedores into visible public figures whose projection transcends the community setting'. ${ }^{42}$ This has had important implications over the years, as will be seen in the next section. However, the success of these popular women leaders began to create a divide between themselves and the women involved with the day-to-day running of the comedores, as the leaders began to engage with a wider network of actors. As Barrig states:

these leaders ... have discovered in the fulfilment of their responsibilities a vehicle for upward social mobility which gives them access to the offices of the mayor and the bishops, the corridors of the various ministries, and even the President of the Republic. In addition, they are interviewed and photographed by the alternative press as well as the mass media. ${ }^{43}$

Although they gained certain skills and experience, it appears there was no deliberate knowledge transfer by the dirigentas to other members of the comedores, somewhat undermining the collective nature of the organisations and giving the dirigentas a relative degree of power. Leadership at the grassroots level thus provided possibilities for progress and upward mobility for a few charismatic women, but although such organisations were clearly a leap forward in terms of women's collective emancipation and engagement in a wider sphere beyond their own homes, the leadership paradigm that emerges from examining these formative experiences of community organising still appears to be based on vertical power relationships and clientelism rather than on horizontal, participatory practices. Importantly, in terms of fomenting empowerment and social change through collective organising, towards the end of the r 980 s Blondet concluded that:

The women have learnt about the city, organisation and the urban poor, however their participation has not moved beyond the limits of the family. They struggle for better living standards for their own (para los suyos) but without yet coming to constitute an organised social and political force that demands an examination of conditions of subordination in daily life and in women's work. ${ }^{44}$

Blondet recognises that women's participation in collective organising at this time was an attempt to improve their living standards and ensure the survival of their families rather than a militant struggle for social change. ${ }^{45}$ However,

${ }^{41}$ Barrig, 'Women, Collective Kitchens and the Crisis of the State'; Cecilia Blondet, 'Out of the Kitchens and onto the Streets: Women's Activism in Peru', in Amrita Basu (ed.), The Challenge of Local Feminisms: Women's Movements in Global Perspective (Oxford: Westview Press, I 995), pp. 25 I-75.

${ }^{42}$ Barrig, 'Women, Collective Kitchens and the Crisis of the State', p. 71. ${ }^{43}$ Ibid., p. 73.

${ }_{44}$ Blondet, 'Muchas vidas construyendo una identidad', p. 70, my translation.

${ }^{45}$ See also Molyneux's discussion of practical versus strategic gender interests in Maxine Molyneux, Women's Movements in International Perspective (Basingstoke: Palgrave, 200 I). 
alongside these instances of women's organising in the barriadas, there also emerged an idealistic generation of middle-class university students and newly qualified young professionals who were committed to working towards progressive social change. Many of these groups of activists began to initiate and get involved in popular education projects in Lima's barriadas in the $1980 \mathrm{os}$, using the radical notions of empowerment and participatory approaches discussed above. ${ }^{46}$ They used the clubes de madres and comedores populares to access ready-made groups of women with whom to collaborate, bringing a more politicised agenda into these spaces. The development of women's leadership formed a key element of this emancipatory activism and popular education, reflecting Wieringa's conceptualisation of empowerment. ${ }^{47}$ Blondet also notes that by the mid-r 980 os the comedores were beginning to coordinate with other organisations such as trade unions, neighbourhood organisations and political parties. ${ }^{4}$

This politicised context is evident in the creation of the Esperanza NGO by a group of middle-class feminists in 1980. These women began by analysing their own experiences of gendered subordination, but quickly found commonalities with the lives of women from other backgrounds. They developed a proposal to work with popular women's organisations, holding workshops designed to facilitate women's reflection on the gendered oppression that shaped their lives. An agenda for far-reaching social and political change, with an emphasis on gender equity, was at the heart of all Esperanza's interventions, and this was exemplified by their early work with a group of women in Barrio Alegre, some of whom would later become health promoters. When the women from Esperanza first started working in the barriada their methodology was, by their own admission, vague and largely improvised, but they had endless enthusiasm for sharing their ideas with grassroots women:

The first time we had a meeting, a workshop about health ... we taught the women how to use contraceptives by demonstrating on ourselves ... A colleague with a little mirror taught them how to insert a rubber thing there was, what was it called? I don't know if they even still exist ... a diaphragm ...

The women were terrified! Because they weren't accustomed to showing their intimate parts ... But we were proud! We taught them, 'we must teach this to the women!' These days the focus, the methodology, it has all shifted $\mathrm{r} 80$ degrees ... Now there's all this cultural element ... My goodness! Much more technical, much more scientific, much more methodological, with measurements ...

Marisol, Esperanza founder

This quote from Marisol highlights the 'hands-on' nature of Esperanza's approach, while also alluding to the subsequent professionalisation and

${ }^{46}$ Francesca Denegri, Soy señora: testimonio de Irene Jara (Lima: IEP, 2000).

47 Wieringa, 'Women's Interests and Empowerment'.

${ }^{48}$ Blondet, 'Muchas vidas construyendo una identidad'. 
NGO-isation of Esperanza, which frames the shifts outlined below. ${ }^{49}$ Esperanza's early workshops emphasised participatory learning in a nonhierarchical environment, focusing on strengthening women's grassroots organisations and promoting change through consciousness-raising workshops that dealt with issues of identity, sexuality, self-esteem, work and community organising. ${ }^{\circ}$ Esperanza recognised the significance of the women who were emerging as community leaders in the 1980 s and prioritised the development of their skills as grassroots leaders as a key element for furthering its own feminist agenda.5 ${ }^{5}$ Esperanza also recognised that prior involvement in community organising would probably make women more likely to be interested in becoming a health promoter and more suitably skilled to take on the role. Correspondingly, in my interviews with the health promoters, it transpired that the majority of them had previously held a community leadership role.

When Esperanza first started working in Barrio Alegre in 1982, what it was doing was radical and challenging to the status quo. Feminists were viewed with suspicion as sexually liberated women who wanted to dominate men and who encouraged women to leave their husbands:

It was very difficult because - I don't know if you know, but because it's a feminist organisation, the community rejected it ... even now, but now much less so. Even us, as people from the community, our own husbands didn't want to know us, because they said that the women from Esperanza taught us to cheat on our husbands, that they taught us to be liberal women, they let us know our rights ...

Elena, health promoter

Health issues provided an entry point for Esperanza's work in Barrio Alegre, as this was seen to be more acceptable and less threatening than an overtly feminist agenda. The NGO took a practical, hands-on approach to its work in Barrio Alegre, forming close and affectionate relationships with the women of the community, who remember these early experiences with great fondness. Over time, the NGO developed a close working relationship with a group of these women, and together they identified reproductive health issues as a particular problem in the community.

Echoing the broader feminist development discourses discussed above, issues of women's empowerment were conceived as having transformative

49 For a more detailed discussion see Katy Jenkins, 'Practically Professionals? Grassroots Women as Local Experts - A Peruvian Case Study', Political Geography, 27: 2 (2008), pp. $139-59$.

so See Liam Kane, Popular Education and Social Change in Latin America (London: Latin America Bureau, 200I), for a review of the role of popular education in social movements in Latin America.

51 Christina Hee Pedersen, Nunca antes me habian enseñado eso: capacitación feminista - metodología/comunicación/impacto (Lima: Lilith Ediciones, 1988). 
potential and were central to Esperanza's philosophy during the I970s and I 980 s, forming a key part of its politicised agenda. Esperanza explicitly linked its work in Barrio Alegre around sexual and reproductive health to a process of empowerment. One of its basic premises was the use of 'self-consciousness and information about healthcare as a tool for autonomy and empowerment'.52 Teaching women about their bodies and basic sexual and reproductive health in a participatory environment formed part of an ongoing process of empowerment, reflecting Hlupekile's notion of empowerment as control - in this case, women gaining control over their own bodies and fertility. 53 Importantly, this feminist empowerment approach included an emphasis on encouraging grassroots women leaders' progression and personal development, in contrast with the current, more hegemonic usage of 'empowerment' by multilateral organisations, which tends to be more focused on efficiency, entrepreneurship and attaining specific project targets. 54

Traditional forms of organising have been transplanted into and adapted in an urban context through contemporary processes of migration and settlement. 55 The election of community leaders has been a prominent feature of urban settlement, introduced by migrants whose precarious situation implied a need to organise, and who elected dirigentes to represent their local neighbourhood in negotiations at higher-level community assemblies and with governmental officials. ${ }^{6}$ While the role of the health promoters is not one of being a dirigenta (although some of them are dirigentas as well), the importance placed by Esperanza on fomenting grassroots leadership in these early days is evidenced in the extent to which the identity and status of all the health promoters is rooted in their community's perception and recognition of them as dynamic and respected lideres (leaders), 57 in the broad social sense of the word:

What is it that motivates me to carry on doing this job? It's that the women recognise us now. You see? They recognise us and they come and look for us, even my own family now, you see?... My daughters, my husband and the women are what motivate

52 Project literature, my translation.

53 Sara Longwe Hlupekile, 'Towards Realistic Strategies for Women's Political Empowerment in Africa', in Sweetman (ed.), Women and Leadership, pp. 24-30.

${ }^{4}$ Sweetman, 'Editorial'; Batliwala, 'Taking the Power out of Empowerment'; Aruna Rao and David Kelleher, 'Leadership for Social Transformation'.

s5 Rosa Alayza Mujica and Mercedes Crisóstomo Meza, 'Women's Rights in Peru: Insights from Two Organizations', Global Networks, 9: 4 (2009), pp. 485-506; Jeanine Anderson, Leoncio Prado: su historia, su palabra (Lima: SINCO Editores, 2002).

${ }^{56}$ Blondet, Las mujeres y el poder. 'Dirigentes' is the term for a formally elected community leader and can include women and men, but in practice dirigentes tended almost always to be men until the i980s. For a discussion of the role of community dirigentes/dirigentas, see Anderson, Leoncio Prado.

57 Líderes are individuals who are respected in the community, but are not necessarily elected representatives (dirigentes). 
me. Because here, in the community, they come and find us. That's what makes me feel good, you see?

Elena, health promoter

The concept of a líder is particularly Andean in its origins and is rooted in traditional forms of community organising. To be a community leader traditionally bestows a certain social status on an individual but also carries particular obligations, especially in relation to organising (and funding) community events and fiestas. ${ }^{58}$ Building on the struggles and experiences of the clubes de madres and the comedores populares, the Integra project is the latest in a series of women's community organisations that have incrementally challenged how the notion of a líder is constructed. As the women have become accepted and respected in the community for the work they do, they have come to be considered as líderes. To achieve this position of high regard in the community has involved investing a great deal of time and energy, as the health promoters were certainly not viewed in this way when the project first began: 59

But in the beginning it was difficult, very difficult. They shut the doors in our faces, they said to us, 'Yes, here come the ones who cheat on their husbands [las sacavuelteras]. Yes, it's because of this that their husbands are leaving them!' There was so much criticism of us, you know? But, bit by bit we've managed to get over it, making them realise that it's not like that.

Susi, health promoter

Susi's comments remind us of the struggle that grassroots women faced in becoming involved in activism, ${ }^{60}$ and illustrate the opposition that the health promoters faced in the community and in their families at this time, when feminism was viewed with suspicion and a culture of machismo was the norm. ${ }^{6}$ This again emphasises the politicised nature of experiences of women's activism in the barriadas in the I980s and early I990s, as grassroots women collaborated closely with feminist activists.

However, the politicisation of women's organising and these early experiences of building solidarity during the I 980 s were brutally disrupted by widespread political violence and the activities of the left-wing Maoist guerrilla organisation Sendero Luminoso (Shining Path, SL) and state counterinsurgency forces in Lima's barriadas, precluding the development of a more coherent or politicised popular women's movement.

${ }^{58}$ Giorgio Alberti and Enrique Mayer, Reciprocidad e intercambio en los Andes Peruanos (Lima: Instituto de Estudios Peruanos, 1974). $\quad 59$ Jenkins, 'Practically Professionals?'.

${ }^{60}$ Denegri, Soy señora.

${ }^{6 r}$ See also Madhok, 'A Limited Women's Empowerment', for a very similar discussion in the Indian context. 


\section{Grassroots Women Leaders in the Line of Fire}

The internal war between SL and the state's counterinsurgency forces had a profound effect on the course of development in Peru in the I980s and I990s, destroying much of the country's social, economic and political fabric. ${ }^{62}$ An estimated 69,000 people died during the 20 years of guerrilla and state violence that began in 1980.63 Having initially been active in highland areas, SL began its assault on Lima towards the end of the 1980 s. With such a concentration of poor, working-class people, the barriadas were a key staging ground for SL. It aimed to eliminate all possible opposition, and thus not only the state but also community organisations such as popular education centres, church activities and neighbourhood associations were perceived as a threat. Left-leaning organisations and community activists were a particular problem for SL as they provided a viable and well-organised alternative to it, and they thus bore the brunt of the assassinations and violence. High-profile activists, NGO workers, progressive members of the clergy and community leaders were all targeted for intimidation and violence, and in many cases were assassinated. ${ }^{64}$ As a crucial part of the social fabric of the barriadas, and often one of the few things holding communities together and enabling their survival, the popular women's organisations represented a real threat to SL's ambitions. ${ }^{65}$

Neighbourhood dirigentas were central in shaping local opinion and were at the height of their prestige at this time, and for this reason they became prime targets for SL. ${ }^{66}$ Both the Truth and Reconciliation Commission and Human Rights Watch highlight that leaders of women's organisations received no protection from the government and were thus highly vulnerable to attack. ${ }^{67}$ Women's organisations in Lima provided one of the few organised opposition forces to SL, but violence and intimidation gradually eroded these organisations and their alliances in the community. ${ }^{68} \mathrm{Few}$ women leaders

${ }^{62}$ See David Scott Palmer (ed.), Shining Path in Peru (London: C. Hurst \& Co, 1992), for a detailed discussion of this history.

63 Truth and Reconciliation Commission, 'Final Report' (Lima: Comisión de la Verdad y Reconciliación, 2003).

${ }^{64}$ Deborah Poole and Gerardo Renique, Peru: Time of Fear (London: Latin America Bureau, I 992 ).

65 Cecilia Blondet, 'In No-Man's Land: Poor Women's Organizations and Political Violence in Lima's Neighbourhoods', in John Friedmann, Rebecca Abers and Lilian Autler (eds.), Emergences: Women's Struggles for Livelihood in Latin America (Los Angeles: UCLA Latin American Center Publications, 1996), p. 85.

${ }^{66}$ Truth and Reconciliation Commission, 'Final Report'.

${ }^{67}$ Ibid.; Human Rights Watch, 'The Human Rights Watch Global Report on Women's Human Rights' (New York: Human Rights Watch, undated).

${ }^{68}$ Mujica and Meza, 'Women's Rights in Peru'; Human Rights Watch, 'The Human Rights Watch Global Report.' 
risked publicly opposing SL, and those who did were often murdered, as in the high-profile case of Maria Elena Moyano, a grassroots feminist activist assassinated by SL shortly after making a speech denouncing its activities in 1992. ${ }^{69}$ Through its targeting of prominent grassroots leaders, SL managed to paralyse Lima's popular organisations, accelerating their decline in an atmosphere of terror and suspicion. The women who participated in this research lived through these brutal and chaotic events. The violence of this time was seldom openly discussed during my interviews with health promoters, but as prominent individuals involved in grassroots activism, members of Integra and Esperanza received death threats from SL. The Integra clinic was also targeted, with two promoters being forced to leave the community temporarily.

SL's activities had a widespread and wholly negative impact on the organising capacity of women in Lima's barriadas. SL's specific targeting of grassroots leaders made being a 'leader' a risky undertaking with enduring negative connotations, and left a largely disarticulated grassroots women's movement with few leaders. In this context we also see the beginnings of a process of distancing between grassroots women and feminist organisations, as NGOs such as Esperanza were temporarily forced to suspend work in the barriadas..$^{70}$ Those women who continued to be involved in community organisations during the time of SL mostly concentrated on maintaining a low profile and emphasising the service provision aspect of their work, and avoided engaging with wider political agendas. ${ }^{71}$ This pattern has continued into the present day, albeit to a lesser extent, with a general lack of coordination between community women's organisations, something also manifested in this case study. ${ }^{72}$

By 1990, when President Alberto Fujimori was elected, Peru was in turmoil - state power had been almost completed eroded and ceded to the military. ${ }^{73}$ This situation facilitated Fujimori's imposition of an increasingly authoritarian regime; by 1991, Fujimori had extended emergency zones to cover 40 per cent of Peru's territory and half its population. ${ }^{74}$ Soon after coming to power Fujimori began the implementation of a heterodox set of neoliberal reforms, with the infamous 'Fujishock' leading to a renewed emphasis on women's organisations as providers of social welfare in times of

69 Truth and Reconciliation Commission, 'Final Report'; Blondet, 'In No-Man's Land'.

70 Jenkins, 'Practically Professionals?'; Mujica and Meza, 'Women’s Rights in Peru'; Anderson, Leoncio Prado.

${ }^{71}$ Barrig, 'Women, Collective Kitchens and the Crisis of the State'.

${ }_{72}$ Blondet and Montero, Hoy: menú popular.

${ }^{73}$ Kenneth Roberts and Mark Peceny, 'Human Rights and United States Policy Toward Peru', in Maxwell A. Cameron and Philip Mauceri (eds.), The Peruvian Labyrinth: Polity, Society, Economy (University Park, PA: Pennsylvania State University Press, 1997), pp. 192-222.

${ }^{74}$ Ibid., p. 198. 


\section{I 4 Katy Jenkins}

crisis. ${ }^{75}$ These extreme conditions allowed Fujimori to initiate a self-coup in April 1992, initially widely supported by the population. ${ }^{76} \mathrm{With}$ the justification of fighting SL, Fujimori's self-coup suspended the Constitution, dissolved Congress and reorganised the judiciary. ${ }^{77}$

Grassroots organisations became increasingly fragmented during the Fujimori dictatorship, which saw a continuation of the authoritarianism, human rights abuses and military impunity that had dominated much of the I980s. ${ }^{78}$ This situation was exacerbated and largely orchestrated by the shadowy figure of Vladimiro Montesinos, an ex-spy and drug trafficker who infiltrated the highest echelons of Fujimori's government and clandestinely headed the notorious Servicio de Inteligencia Nacional (National Intelligence Service, SIN). ${ }^{79}$ Over the course of a decade, Montesinos and Fujimori effectively dismantled the mechanisms of the state and manipulated them to serve their own interests. ${ }^{80}$ It was only in 2000 that Peru was able to begin the process of rebuilding its fragile social fabric, after Fujimori resigned and both he and Montesinos fled the country. ${ }^{8}$ An understanding of this destruction and fragmentation wrought by both SL and the Peruvian government (principally via the military), at every level of Peruvian society over a 20 -year period, is crucial to an analysis of the current position of grassroots women and community organisations in the country. Not only have conceptions of leadership among grassroots women been informed by generalised neoliberal constructions of women's leadership and empowerment, but this particular political backdrop has also been a key factor in shaping the depoliticisation of grassroots women's leadership practices in Peru. The grassroots organisations and activists that endured these years of violence and instability were put under immense strain, compounded by a general sense of fatigue after having been involved in community organising for so long. ${ }^{82}$ Now, almost 30 years on from the heyday of urban women's organising, much of this popular women's movement appears to have lost its momentum, a direct consequence of the violent history outlined above and of the manipulation of women's

75 Boesten, 'Poor Women in Peru'.

${ }^{76}$ Maxwell A. Cameron and Philip Mauceri (eds.), The Peruvian Labyrinth: Polity, Society and Economy (University Park, PA: Pennsylvania State University Press, 1997).

77 Poole and Renique, Peru: Time of Fear; Cameron and Mauceri (eds.), The Peruvian Labyrinth.

${ }^{78}$ Cameron and Mauceri (eds.), The Peruvian Labyrinth.

79 Gustavo Gorriti, 'The Spy Who Would Rule Peru' (Washington, DC: Center for Public Integrity, 2005), available at www.globalintegrity.org/reports/2004/default997a.html? act $=23$.

80 Ernesto García Calderón, 'High Anxiety in the Andes: Peru's Decade of Living Dangerously', Journal of Democracy, I 2: 2 (2001), pp. 46-58.

${ }^{81}$ Gorriti, 'The Spy Who Would Rule Peru'.

${ }^{82}$ Katy Jenkins, “We have a Lot of Goodwill, but We Still Need to Eat ...”: Valuing Women's Long Term Voluntarism in Community Development in Lima', Voluntas: International Journal of Voluntary and Non-Profit Organisations, 20: I (2009), pp. I 5-34. 
organisations by the Fujimori regime, 'convert[ing] temporary poverty relief into a structural practice that depended entirely on the voluntary work of women'.83

At the time of this research, Peru was in a post-Sendero, post-Fujimori era under President Toledo, with both the state and mainstream development institutions emphasising a neoliberal approach to development. Bury notes that Peru has become 'one of the most open and liberal economies ... in the world' following the rapid neoliberalisation of the economy during the I 990 , with an emphasis on privatisation and market-led reforms, and Arce suggests that this economic liberalisation has led to a re-politicisation of collective action in Peru. ${ }^{84}$ Arce focuses on protests, however - he does not consider other forms of collective action, and in particular does not examine gendered spaces of collective organising with their long historical trajectory. The remainder of this paper therefore explores narratives of women's grassroots leadership, arguing that it is essential to situate understandings of gendered leadership and collective organising within a community's political and historical trajectory rather than simply in terms of the universalised, neoliberal 'best practice' discussed above. This discussion contributes to a more nuanced analysis of processes of de/politicisation under neoliberalism in Peru.

\section{Depoliticisation and Changing Leadership Practices in the Integra Health Promotion Project}

As outlined above, the leadership style that developed at Integra during the I 980 s was framed by an overarching ethos of collective empowerment and a desire to challenge existing gendered social structures. This approach emphasised horizontal structures and rotating leadership, and encouraged participation and the health promoters' relative autonomy, albeit guided and supervised by Esperanza. However, the wider scenario in which the Integra clinic and the health promoters now operate is very different. While women's organisations in Peru have enabled the survival of communities over many years, it appears that they have not facilitated ordinary women members' politicisation through reflection on the causes of their marginalised position, nor generated a sustained political agenda. ${ }^{85}$ Additionally, as barriada communities

83 Boesten, 'Poor Women in Peru', p. i 16.

${ }^{84}$ Jeffrey Bury, 'Mining Mountains: Neoliberalism, Land Tenure, Livelihoods, and the new Peruvian Mining Industry in Cajamarca', Environment and Planning A, 37: 3 (2005), p. 223; Moisés Arce, 'The Repoliticisation of Collective Action after Neoliberalism in Peru', Latin American Politics and Society, 50: 3 (2008), pp. 37-61.

${ }^{85}$ Jenkins, 'Practically Professionals?'; Pepi Patrón, 'Presencia social, ausencia política: espacios públicos y participación feminina' (Lima: AGENDA Perú, 2000), available at www. agendaperu.org.pe/pdfs/pub-05.pdf; Themis Castellanos del Portal, Rosalia Caramutti and Mercedes Ubullis, "Lo “viejo” y lo “nuevo" de la acción colectiva en Lima: experiencias de 


\section{I Katy Jenkins}

have become more established, collective organising has become less widespread. ${ }^{86}$ Younger generations of women are also less inclined to get involved in collective organising, often preferring paid employment to voluntary work in community organisations and employing different survival mechanisms as a result of having grown up in the city. ${ }^{87}$

Such fragmentation of grassroots interests also reflects an increasing distance between the predominantly middle-class feminist movement and popular women's organisations. ${ }^{88}$ While the latter were very active in the I 980 s and I990s, the middle-class feminist movement tended to be the catalyst for mobilising these women for political ends. As alliances between these groups have become more tenuous, it has become less possible to identify any sort of cohesive 'women's movement' in the barriadas. Eckstein recognises this process in relation to Latin America more generally, noting that women's concerns have become less focused on political protest and more rooted in their particular class-based and ethnic context. ${ }^{89}$

While feminist organisations such as Esperanza have become more professionalised (with the associated challenges that this brings), focusing on strategic issues such as democracy and women's representation in the political sphere, women in the barriadas continue, out of necessity, to focus on subsistence and daily survival. ${ }^{\circ}$ Below, I therefore consider how grassroots leadership is being re-worked in this new scenario, exploring the Integra health promoters' practices within an increasingly depoliticised context.

\section{Leadership without the politics?}

As discussed above, feminist conceptions of empowerment emphasised women's leadership as a key aspect of a long-term process of promoting social change in grassroots communities, providing an explicitly politicised agenda for popular women's organisations in the 1980 . However, as feminist organisations have become $\mathrm{NGO}$-ised $^{91}$ and women's organising has become

participación ciudadana' (Austin, TX: Center for the Study of Urbanization and Internal Migration in Developing Countries, 2003). $\quad{ }^{86}$ Anderson, Leoncio Prado.

${ }^{87}$ Interview with Natalia González, Instituto de Estudios Peruanos, Lima, 2003.

${ }^{88}$ Katy Jenkins, 'Exploring Hierarchies of Knowledge in Peru: Scaling Urban Grassroots Women Health Promoters' Expertise', Environment and Planning A, 4I: 4 (2009), pp. 879-95.

89 Susan Eckstein, 'Where Have All the Movements Gone? Latin American Social Movements at the New Millennium', in Susan Eckstein (ed.), Power and Popular Protest: Latin American Social Movements (Berkeley, CA: University of California Press, 2001), p. 384.

90 Jenkins, 'Practically Professionals?'.

${ }^{91}$ Sonia E. Alvarez, 'Latin American Feminisms "Go Global": Trends of the r 990 os and Challenges for the New Millennium', in Sonia E. Alvarez, Evelina Dagnino and Arturo 
more fragmented, this politicised context has become less prominent. How then might we understand the current position of this unique generation of Peruvian women who have dedicated much of their lives to community activism?

Ideas around leadership roles and responsibilities emerged as central to the promoters' experiences, and their interviews provide an insight into the increasingly depoliticised nature of grassroots leadership and activism. There are various roles that can be identified as 'leadership' positions within the Integra clinic: a coordinator for the group delivering health promotion workshops (Sandra), and two coordinators for the team that runs the clinic (Elena and Fatima). Additionally, Julia is the coordinator responsible for overseeing the whole of the health project. These four coordinators are paid more than the basic health promoters, but their positions are full-time ones, officially 40 hours a week but in reality often much more, with the boundary between work and home life often becoming blurred. I do not want to suggest that only the health promoters who occupy formal leadership positions within the Integra hierarchy should be seen as leaders; the leadership model that has developed over the years draws as much on informal leadership mechanisms as on formally assigned positions of authority, with the longest-serving health promoters such as Anita and Susi being respected for their knowledge and experience.

However, my research highlights an apparent shift towards new managerial practices in the way in which Integra is organised, with management skills being concentrated in a few key people in order to promote greater efficiency and accountability. These skills are increasingly perceived to be essential by Esperanza, as Integra begins to be incorporated into a professionalised style of development practice based around meeting targets and producing statistics and quantifiable results. For example, while previously there had apparently been little in the way of systematic efforts by Esperanza to evaluate and monitor Integra's impact, donors increasingly require Esperanza, and thus the Integra promoters, to produce reports (both qualitative and quantitative) summarising their monthly activities, such as recording the number of women who have attended workshops and the number of smear tests carried out. This provides insight into the ways in which the everyday work of the health promoters has been depoliticised, with the long-term objectives of women's empowerment and education being reduced to a series of indicators, and the health promoters' activities becoming focused on service delivery. Madhok's discussion of an Indian programme around empowerment in which 'the 


\section{I 8 Katy Jenkins}

radical empowerment component of the programme has been effectively silenced and ... exists only as a caricature of the original programme' as the grassroots women have become embroiled in 'administrative procedures, reports and inspections and the collection of statistics and setting of tangible development targets' resonates strongly here..$^{2}$

This depoliticisation and shift to a service delivery focus is also evident in the scope of the promoters' everyday activities. Notably, the emphasis on gender relations, feminism and empowerment, which was central to the work of Esperanza and its training of the health promoters, was largely lost when the health promoters taught others. This was evident in workshops for community women being trained to act as first points of contact in the community: after a I 2-week course, very few of them understood the concept of gender that was supposed to underpin all of the workshops. ${ }^{93}$ There was no sense of challenging women to evaluate their own lives and relationships, but rather a much narrower focus on health issues - such as sexually transmitted diseases and contraception - without any explicit discussion of the gendered nature of reproductive health, and of health and health care more generally.

This lack of critical perspective was evident in many of the workshops that the promoters carried out with community women. In one exercise, groups of women were given pictures of different tasks - driving a lorry, cooking, building a house, feeding a baby and so forth - to sort into categories of 'tasks women do', 'tasks men do' and 'tasks both women and men do'. After 20 years of feminist activism in their community, the women had clearly got the message that women can do anything men do, and that men should contribute to traditionally female household chores. So, in almost every workshop I attended, every task except breastfeeding was sorted into the category of 'tasks both women and men do'. The women had a clear idea of what was expected of them and performed accordingly, but with no reference to the reality of their own households, and the tasks that men and women actually carried out. The health promoters did not pick up on this or push the women to analyse the situation more closely, and thus the critical stance on gendered household relations, which had presumably originally characterised this task, was entirely diluted.

I also witnessed this lack of critical engagement in the preparations for a protest march organised for International Women's Health Day on 8 March 2003. All the health promoters and women involved in Integra workshops were encouraged by Esperanza staff to attend and to bring their female friends, but there seemed to be little political engagement on the part of any of the women in terms of understanding what they would be protesting about.

92 Madhok, 'A Limited Women's Empowerment', p. 164.

${ }_{93}$ Esperanza internal project evaluation, 2003. 
Esperanza staff told me that the march was to protest the decline of reproductive health services - lack of access to contraception, the government's attempted banning of the morning-after pill, and the generally conservative stance of the Ministry of Health - but this was not made explicit to the community women who were encouraged to attend. ${ }^{94}$

The promoters' everyday leadership practices in their community therefore appear to retain little of the explicitly politicised agenda for change that previously characterised them, although some elements of a more radical agenda for social change are still evident in their organising structures. Weekly meetings of the health promoters and coordinators form the main organisational mechanism at Integra, and these reflect traditional organising strategies of collective decision-making by assembly, and suggest the continued influence of feminist participatory mechanisms based on horizontal power relations and an 'alternative' development approach. We therefore see a weaving together of the originally collective, participatory ethos of Integra, elements of professionalised neoliberal development practices, and the particular socio-political circumstances outlined above. This creates tensions and a certain degree of confusion among individual actors at the grassroots level and between the health promoters and Esperanza, undermining the potential for transformatory and empowering practices to be enacted in an increasingly depoliticised and fragmented context.

\section{Knowledge transfer and leadership development}

Such tensions are particularly evident in the concentration of leadership responsibilities in a few key people at Integra. These women are elected to the post of coordinator by the whole group of promoters, and it is a position that is meant to last for two years. However, despite this rotating model, Julia has apparently held the position of overall health services coordinator almost constantly. As well as being the overall coordinator for the health section, Julia is in charge of the wider community project of which the health promotion project is a part. This suggests that there is excessive concentration of power in the hands of one individual, albeit one highly competent and motivated individual, and the promoters themselves recognised this as a problem:

More than anything what we can't manage ourselves is the economic aspect, and this is something that limits us a lot. It divides us quite a lot because we think that there's just one person who has all the power, you see? And I know that if we lost this person we would be back at zero. Why? Because we are not learning how to transfer these skills. This transfer should be of knowledge, but also of administrative skills,

${ }^{94}$ In the end, the march did not go ahead, as President Toledo declared a national state of emergency the night before. 
accounting ... But, for us, the administrative aspect is a weakness. It's very centralised in just one person.

Anita, health promoter

Julia recognised that she shouldered a disproportionate share of responsibilities and was trying to avoid this happening too much in the future. However, despite her good intentions, the situation is perpetuated by a lack of skills transfer to other members of the group to enable them to take on a coordinating role, something the health promoters highlighted to me in the interviews:

Sometimes, one or two people have all of the energies put into them - they only train her, her, her, her. But when she can't do it, to whom will she delegate? There's no one. She can't delegate because no one else has been given the opportunity to learn - that is, no one else knows. The other person would have to teach me, so that I could do it. And of course you spend time on that too, do you understand me? ... So sometimes, one or two people accumulate all the skills and others don't get the chance.

Pilar, health promoter

This is not a problem caused particularly by Julia, and certainly not in any malicious way, but more a case of the project not having the formal mechanisms in place, and the promoters not necessarily having the enthusiasm or spare time, to ensure that this knowledge transfer can occur. In theory, rotating leadership should facilitate this sort of knowledge and skills transfer between members, but in this case it appears not to be happening. Rowlands discusses a similar situation among a group of health promoters in Honduras, resonating with the experiences of the Integra promoters:

[The coordinators] were not in turn encouraged to foster the development of leadership skills among other members of their groups. In Rosa's case, having been elected to coordinate the circle, she became the only person taking responsibility for group activities. If anything needed leadership, she was the one to do it, taking on the role of treasurer and organiser of their 'credit union' as well. That boosted her selfconfidence because of her group's confidence in her, but also limited the opportunities for personal development for other members. ${ }^{95}$

This could suggest that the experiences of the Integra promoters are not unusual but rather reflect much broader changes within grassroots organising, as neoliberal development paradigms of efficiency and specialisation impact across Latin America (and beyond). However, I argue that what may initially appear to be simply the dominance of neoliberal efficiency through the rationalisation of leadership responsibilities is actually part of a more particular process of depoliticisation in Peru, manifested in a general reluctance on the part of the health promoters to assume leadership roles. Relatively little of this shift can be attributed to the direct imposition of a neoliberal development

95 Rowlands, Questioning Empowerment, p. 64. 
model; rather, it results from the interweaving of changing development practices with the specific socio-political and historical scenario in which Integra has evolved, where women's activism has become a mechanistic and depoliticised response to the continued lack of adequate provision of health care and other key services, increasingly distant from explicit feminist consciousness-raising and transformatory processes of empowerment and knowledge transfer.

\section{Reluctant leaders?}

A lack of dynamic leadership was evident throughout my time at Integra, creating a general sense of stagnation and loss of momentum on the part of the promoters. In particular, there seemed to be a deep ambiguity in the promoters' construction of leadership, manifesting itself in their widespread reluctance to adopt leadership roles and responsibilities. Much of this reluctance must surely stem from the women's experiences during the 1980 s and I990s, when SL's targeting of grassroots women leaders meant that assuming a prominent leadership position was a risky undertaking, with widespread violent repression in women's communities. Despite the cessation of SL violence and the end of the Fujimori regime, this has clearly left grassroots women with enduring negative connotations of leadership, and this is accompanied by the wider process of the fragmentation of women's organising and the ensuing lack of wider political context. ${ }^{96}$

The health promoters themselves, however, frame their reluctance to take on coordinator roles around issues of the triple burden, highlighting the difficulties they face in juggling quite demanding voluntary work with domestic responsibilities and often other paid work:

Yes, well ... it's lovely to be a coordinator. But the thing is, you see, they abandon, I don't know, everything to be done at home. Because you dedicate yourself more to your work, to Integra, and suddenly you forget a bit about your family. You go out in the morning and you come home at night, you don't even have lunch with them, you spend all your time here at the clinic ... Most of your time. It's a big responsibility. It's a burden ... Of course, if you're not going to take it seriously, you won't reach your targets. But if you take it seriously, you're going to make sure you achieve everything that you want to.

Isabela, health promoter

This 'triple burden' is clearly nothing new when considering the situation of poor urban women involved in community organising. ${ }^{97}$ In this particular

${ }_{96}$ The Integra promoters had no contact with other types of civil society organisation such as trade unions.

${ }^{97}$ Boesten, 'Poor Women in Peru'; Maxine Molyneux, Change and Continuity in Social Protection: Mothers at the Service of the State, Gender and Development Papers no. I 


\section{Katy Jenkins}

scenario, however, the specific association of the triple burden with the assumption of leadership duties serves to illustrate another negative association that the health promoters make with leadership responsibilities. Importantly, in terms of the overlaying of different neoliberal development practices over time, Isabela's comment above particularly suggests that the triple burden is exacerbated by an increasingly target-driven approach.

Several coordinators past and present commented on the strain put on them and their family by their commitments as coordinators, ${ }^{98}$ and stressed the incompatibility of the role of coordinator with bringing up young children:

I don't have time to do a lot of the chores at home; my children, I don't have time to do the washing. It's because of this that I don't like to come to work on Saturdays. Because my children have to wash themselves. Because during the week I work from Io in the morning until 6 at night.

Sandra, health promoter

They also chose me last time. They said to me, 'If you were chosen to be coordinator again, would you accept?' No, at the moment I'm spending time with my baby, you know? The little girl. Because I took on the job of coordinator when my baby was only two and a bit months old. She was very little. No, she was eight months old, I think. But she was a baby, and I neglected her a lot. Yes, I would come here, and I'd hardly see her; I only saw her at night-time.

Isabela, health promoter

Julia, as the individual promoter with most responsibility, particularly emphasised the problems her job caused in relation to her family responsibilities, asserting that she did not want to continue as coordinator beyond the end of her current tenure. As a feminist NGO whose work has historically focused on consciousness-raising and empowerment, one would have hoped that Esperanza would have been equipped to recognise and address these sorts of issues, but despite their apparent empowerment and emancipation at a community level, the health promoters still have overwhelming responsibility for childcare: empowerment in the community sphere does not automatically translate to empowerment in the domestic sphere.

This persistence of the triple burden suggests that little has changed since Moser's examination of the issue in a low-income neighbourhood

(Geneva: UNRISD, 2007), available at www.unrisd.org/80256B $3 \mathrm{Coos}_{\mathrm{BCCF}} /$ (http:// AuxPages)/BF8oEoA84BE4I 896CI2573240033 C54I/\$file/Molyneux-paper.pdf; Caroline Moser, 'Adjustment from Below: Low-Income Women, Time and the Triple Burden in Guayaquil, Ecuador', in Sarah Radcliffe and Sallie Westwood (eds.), 'Viva': Women and Popular Protest in Latin America (London: Routledge, 1993), pp. 173-96.

${ }^{8}$ See also Cecilia de Mello e Souza, 'Grassroots Leadership in the Network of Healthy Communities in Rio de Janeiro, Brazil: A Gender Perspective', Gender and Development, I6: 3 (2008), pp. 48 I-94. 
of Guayaquil: when women are attempting to juggle competing roles and multiple obligations, it is reproductive tasks in the domestic sphere that are frequently neglected. ${ }^{99}$ One particular afternoon, Isabela told me that she had had to leave her very young child at home alone so that she could come to work. Despite some of the promoters' husbands apparently sharing the household chores, this was still perceived by the promoters (and presumably their husbands) as their husbands 'helping' them, rather than as something which was legitimately a shared responsibility. This underlines the extent to which grassroots women's organising activities have again become delinked from feminist concerns of women's emancipation and equality and have instead focused on service delivery, emphasising the continued contradiction between practical and strategic gender interests in relation to the roles adopted by women in community organising. ${ }^{100}$

These accounts of the triple burden were evident in the experiences of all the health promoters but were particularly prominent in the experiences of those who were, or had been, coordinators. Although undoubtedly a problem for the women, I have no way of knowing to what extent their representation of the triple burden that they faced disguised a more fundamental reluctance to adopt more prominent leadership roles, rooted in their experiences of political violence outlined above. These issues of the triple burden are also undoubtedly augmented by an understandable fatigue, and almost a sense of resignation, on the part of the health promoters after dedicating up to 20 years of their lives to struggling to improve the health and living conditions of their community, leaving them feeling undervalued and largely apolitical rather than emancipated and politicised. Overall, this situation means that the principle of rotating leadership is not actually implemented in practice as few of the promoters are prepared to take on leadership roles. Leadership in this context is not an empowering experience. Thus we see a narrowing of leadership responsibilities, on the one hand reflecting the mainstream shift to an efficiency-led development paradigm, but more specifically reflecting the historical trajectory and depoliticised context in which the health promoters' activism now takes place.

This stagnation of transformatory leadership practices is exacerbated by the health promoters' changing relationship with Esperanza, which no longer provides the inspirational leadership that it once did. A perceived lack of support aimed at helping the health promoters to progress causes a sense of frustration and stagnation whereby the health promoters feel 'stuck' and

99 Moser, 'Adjustment from Below'.

${ }^{100}$ Molyneux, 'Women's Movements in International Perspective'; Caroline Moser, 'Gender Planning in the Third World: Meeting Practical and Strategic Gender Needs', World Development, 17: i I (1989), pp. 1799-825. 


\section{Katy Jenkins}

unable to fulfil their potential. Esperanza's focus has shifted to higher-profile, larger-scale projects with correspondingly larger budgets. Integra has itself become an increasingly marginal element of Esperanza's agenda, 'left behind' as the NGO has engaged with a more donor-led policy agenda beyond the local level. ${ }^{101}$ While Esperanza maintains a commitment to the Integra project, particularly as an exemplar of the organisation's progressive feminist ideology, there is no longer the same substantive ongoing politicised involvement with the promoters on the part of the institution. ${ }^{102}$ Although the health promoters are still ostensibly working within a collective and relatively horizontal structure on a day-to-day level, this is no longer backed up by a radical, empowerment model on the part of Esperanza. We thus see a process of depoliticisation on two levels. Firstly, Esperanza's NGO-isation and engagement in processes of negotiating with international donors and the state requires a less overtly politicised stance. ${ }^{103}$ Secondly, the depoliticisation of Integra is mired in the more everyday practical challenges of providing health care in a poor neighbourhood, without the support of the politicised context at one time offered by the hands-on involvement of Esperanza.

\section{Conclusion}

The overall picture that emerges is of a grassroots organisation struggling to maintain a commitment to a participatory ethos and feminist notions of empowerment in the face of multiple pressures. The research presents a scenario characterised by fragmentation and depoliticised leadership practices at the grassroots level, highlighting a lack of knowledge transfer and active development of new leadership; a lack of ongoing politicised support for the promoters from the Esperanza NGO; and a reluctance on the part of the promoters to take on leadership roles. The promoters' activism is sustained by their narratives of the dynamic, women's collective action framework of the I 980 os, with its emphasis on politicised action, empowerment and grassroots leadership, but the depoliticised context in which they now operate means that there is no longer the momentum to push this agenda forward:

We're always doing the same thing and we're not renewing our knowledge; we're not going to the women with a perspective on how to understand their problems, their life. And we should work with them, with what they give us. But if we're not ... What they gave us 10 or 12 years ago, we're still repeating the same thing. Like a washing machine. We're not living what is happening now; I think this is what is lacking...

Julia, health promoter

${ }^{\text {Iо }}$ Jenkins, 'Exploring Hierarchies of Knowledge in Peru'.

${ }_{102}$ Two or three Esperanza staff members do remain actively engaged in the project, however.

${ }^{103}$ Jenkins, 'Exploring Hierarchies of Knowledge in Peru'. 
The health promoters' situation suggests a fundamental tension between their commitment to activism-sustained throughout economic and political crises - and the contemporary emphasis on service delivery and meeting project targets, which provides little of the sense of progress, empowerment or opportunity for political engagement that once sustained their endeavours. This results in an overall lack of direction and sense of stagnation, with the health promoters increasingly just 'going through the motions' and leaving little room for dynamic grassroots leaders to flourish at the community level.

The health promoters' activist biographies suggest that the politicisation of popular women's organisations in Lima was a partial and relatively short chapter of their history, spurred on by their temporary intimate involvement with middle-class feminist organisations, and a particularly conducive political environment for social organising in Peru in the late 1970 s and early I980s, with the so-called 'transition to democracy'. ${ }^{104}$ While Arce heralds the repoliticisation of collective action in Peru, ${ }^{\text {IOS }}$ the health promoters' experiences point instead to a depoliticised agenda focused on service delivery to fill the continuing gaps in the provision of basic health care services. This scenario also reflects a broader set of challenges highlighted by Cornwall et al., who recognise the need to repoliticise feminism(s) within the field of international development. ${ }^{106}$

This paper has therefore offered a longitudinal account of some of the contradictory forces shaping women's leadership at a community level, providing new empirical material which highlights processes of depoliticisation of women's leadership at the grassroots level in Peru and the associated challenges they bring. While many countries have seen a significant shift to the left and a strengthening of political activism in recent years, including Peru's neighbours Ecuador and Bolivia, the election of Peru's strongly pro-market Alan Garcia (subsequent to the end of the research project) has heralded a further narrowing of political subjectivities and spaces for action. In this context, and drawing on the experiences analysed above, I argue that the continued existence and future development of empowered grassroots women leaders cannot be taken for granted as an unproblematic or linear process arising from grassroots organising but must instead be located within a broader understanding of socio-political histories and personal biographies of activism that

${ }^{104}$ The continued 'democratic deficit' and partial nature of this transition to democracy in much of Latin America is explored in Thomas Carothers, 'The End of the Transition Paradigm', Journal of Democracy, I3: I (2002), pp. 5-21. See also Molyneux, Change and Continuity in Social Protection.

105 Arce, 'The Repoliticisation of Collective Action'.

${ }^{106}$ Andrea Cornwall, Elizabeth Harrison and Ann Whitehead, 'Introduction', in Andrea Cornwall, Elizabeth Harrison and Ann Whitehead (eds.), Feminisms in Development: Contradictions, Contestations and Challenges (London: Zed Books, 2007), p. I. 


\section{Katy Jenkins}

shape the ways in which macro-level development trends articulate with, and are enacted in, specific local contexts.

\section{Spanish and Portuguese abstracts}

Spanish abstract. Este artículo examina cómo las prácticas de liderazgo han sido negociadas y han cambiado en el tiempo en el contexto de un proyecto de base de promoción de salud en Lima, Perú. Rastreando tales trayectorias en el contexto de la evolución de la organización de mujeres en Perú, se establece un análisis más amplio de los cambiantes papeles de las mujeres de base en el desarrollo de los proyectos, alimentando los debates sobre la profesionalización y despolitización del activismo de base, lo que provee nuevo material empírico sobre las experiencias de género en el liderazgo de base. El artículo reconoce el creciente dominio de los mecanismos neoliberales de funcionamiento pero señala que la despolitización de las lideresas de base no es simplemente el resultado directo de prácticas neoliberales de desarrollo sino que ésta se produce en el rejuego de procesos sociopolíticos locales y las experiencias personales de activismo que operan al interior de posiciones y discursos de desarrollo a un nivel más macro.

Spanish keywords: liderazgo de mujeres, profesionalización, Perú, empoderamiento, organizaciones comunitarias, organizaciones de base, despolitización

Portuguese abstract. $\mathrm{O}$ artigo analisa, no contexto de um projeto popular pelo desenvolvimento da saúde em Lima, no Peru, a maneira pela qual práticas de liderança tem sido negociadas e se desenvolvido ao longo do tempo. Essas trajetórias são traçadas no contexto da evolução da organização feminina. A mudança nos papéis exercidos pelas mulheres das bases trabalhando em projetos de desenvolvimento informa uma análise mais ampla, alimentando debates acerca da profissionalização e despolitização do ativismo popular, e fornecendo dados empíricos relativos às experiências de lideranças populares relacionadas ao genero. $\mathrm{O}$ domínio crescente de mecanismos de gerência neoliberais é reconhecido, entretanto argumenta-se que a despolitização de líderes populares femininas não representa a simples percolação de práticas neoliberais de desenvolvimento; outro fator responsável é a interação de processos sócio-políticos locais e biografias pessoais do ativismo com tendências e discursos desenvolvimentistas em nível macro.

Portuguese keywords: liderança feminina, profissionalização, Peru, empoderamento, organizações comunitárias, organização popular, despolitização 